\title{
Pengaruh Kebudayaan, Sosial, Pribadi, dan Psikologi Terhadap Keputusan Konsumen dalam Penggunaan Grab Car pada Mahasiswa Fakultas Ilmu Sosial dan Politik Universitas Sam Ratulangi Manado
}

\author{
Angel Valentino A. P. Maukeno \\ Henny S. Tarore \\ Aneke Y. Punuindoong \\ Jurusan Ilmu Administrasi, Program Studi Administrasi Bisnis, \\ Fakultas Ilmu Sosial dan Politik, Universitas Sam Ratulangi Manado \\ putramaukeno92@gmail.com
}

\begin{abstract}
The purpose of this research is to know the existence of factors influence a company's marketing, personal, social, cultural and psychological effects are significant for consumer behaviour in the use of Grab Car. Consumer behavior is a process undertaken by someone in finding, buying, using, evaluating, and disposing of a product or service after it is consumed, the study was conducted at the Faculty of social and political sciences of the University of Sam Ratulangi Manado by taking 100 students as the respondent. Withdrawal methods used is the sample Random Sampling with data analysis using multiple regression. By using the test validity and reliability in order to test the validity of the data. The results of this research show that cultural factors, social, personal, and psychology at the same time positively and significantly to the decision of the consumer in using the Grab Car with personal factors the most dominant, and it has high determination coefficient values, or have a great contribution towards the decisions of consumers.
\end{abstract}

Keywords: Cultural Factors, Social Factors, Personal Factors, Psychological Factors and Consumer Decisions

\section{Pendahuluan}

Pertumbuhan perekonomian yang semakin pesat dan memerluakan mobilitas yang tinggi, menjadikan transportasi sebagai salah satu faktor yang menunjang kebutuhan masyarakat, sehingga masyarakat akan semakin jeli menentukan pilihan. Pada dasarnya setiap perusahaan itu mempunyai tujuan pokok yaitu memperoleh keuntungan yang maksimal serta memberikan kepuasan pada konsumen. Fenomena transportasi online saat ini sedang hangat diperbincangkan, karena pemesanan berbasis apliksasi yang mudah didownload oleh pengguna smartphone. Pemesanan melalui aplikasi yang mudah membuat transportasi online dengan cepat di terima dikalangan masyarakat, dengan berbagi macam pilihan layanan sehingga mampu memenuhi kebutuhan masyarakat dalam bidang jasa (Anis Agustin, 2017). Dengan kemudahan penggunaan transportasi berbasis online, 
menyebabkan semakin banyak kendaraan pribadi yang di gunakan sebagi transportasi umum dan dapat memperparah kemacetan, selain itu dengan adanya transportasi berbasis online juga menyebabkan masalah antara penyedia jasa (driver) transportasi online dan konvensional. Salah satu penyedia jasa transportasi berbasis online yaitu $G R A B C A R$.

Dalam melakukan keputusan pembelian, konsumen akan sangat dipengaruhi oleh perilaku konsumen itu sendiri. Konsumen dipengaruhi oleh karakteristik kebudayaan, sosial, pribadi, dan psikologi. Mempelajari dan memahami perilaku konsumen akan memberikan petunjuk bagi para pemasar dalam mengembangkan produk baru, keistimewaan produk, harga, saluran pemasaran, dan elemen bauran pemasaran lainnya. Perilaku konsumen menggambarkan bagaiman konsumen membuat keputusan - keputusan pembelian dan bagaimana mereka menggunakan dan mengatur pembelian barang dan jasa.

\section{Tinjauan Pustaka}

Sangadji (2014) dalam Syafirah (2017) mejelaskan perilaku konsumen sebagai suatu studi tentang unit pembelian bisa perorangan, kelompok atau organisasi, unit-unit tersebut akan membentuk pasar sehingga muncul pasar individu atau pasar konsumen, unit pembelian kelompok, dan pasar bisnis organisasi.

Definisi perilaku konsumen menurut Kotler dan Keller (2012) adalah "Tingkah laku konsumen Akhir, baik individu maupun rumah tangga yang membeli barang atau jasa untuk konsumsi pribadi."

Kotler dan Keller (2009) dalam Cindy L. Maleke (2013) mengemukakan manajemen pemasaran sebagai seni dan ilmu memilih pasar sasaran dan mendapatkan, menjaga, dan membutuhkan pelanggan dengan menciptakan, menyerahkan dan mengkomunikasikan nilai pelanggan yang unggul.

Salah satu pengertian menyatakan, bahwa manajemen pemasaran merupakan kegiatan penganalisisan, perencanaan pelaksanaan, dan pengendalian programprogram yang dibuat untuk membentuk, membangun, dan memelihara keuntungan dari pertukaran melalui sasaran pasar guna mencapai tujuan organisasi (perusahaan) dalam jangka panjang (Assuari, 2010) dalam Cindy L. Maleke.

Adapun faktor-faktor yang memengaruhi perilaku konsumen dalam membuat keputusan pembelian menurut Kotler yang kemudian dikutip oleh Bilson Simamora (2004) dalam Juli E.S Towoliu (2017) yaitu faktor budaya, faktor sosial, faktor pribadi, dan faktor psikologi. 
1. Faktor Kebudayaan

Faktor kebudayaan mempunyai pengaruh yang paling luas dan paling dalam terhadap perilaku konsumen. Pemasar harus memahami peran yang dimainkan oleh budaya, sub-budaya, dan kelas sosial pembeli.

\section{Faktor Sosial}

Perilaku konsumen juga akan dipengaruhi oleh faktor-faktor sosial seperti kelompok kecil, keluarga, peran dan status sosial dari konsumen.

\section{Faktor Pribadi}

Keputusan seorang pembeli juga dipengaruhi oleh karakteristik pribadi seperti umur dan tahap daur-hidup pembeli, jabatan, keadaan ekonomi, gaya hidup, kepribadian dan konsep diri pembeli yang bersangkutan.

\section{Faktor Psikologi}

Pilihan pembelian seseorang juga dipengaruhi oleh faktor psikologi yang utama, yaitu faktor motivasi, persepsi, proses belajar, serta kepercayaan dan sikap.

\section{Metode Penelitian}

Pendekatan dalam penelitian adalah pendekatan kuantitatif dengan menggunakan perumusan Hipotesis dan variabel yang digunakan diambil dari teori yang sudah ada, yaitu teori perilaku konsumen. Penelitian ini dilakukan di kota Manado dengan objek penelitian
Mahasiswa. Populasi dari penelitian ini adalah mahasiswa Fakultas Ilmu Sosial dan Politik Universitas Sam Ratulangi Manado, dengan menambil sampel sebesar 100 orang responden. Metode pengumpulan data yang digunakan dalam penelitian ini adalah dengan menggunakan metode kuesioner, dimana kuesioner merupakan pengumpulan data dengan cara mengajukan pertanyaan melalui daftar pernyataan kepada objek penelitain.

\section{Hasil Penelitian}

Berdasarkan hasil prevelensi reponden menurut jenis kelamin menunjukkan bahwa sebagian besar responden yaitu laki-laki sebanyak 55 responden (55\%) dan sisanya adalah responden dengan jenis kelamin wanita sebanyak 45 Responden (45\%). Frekuensi responden berdasarkan usia > 20 Tahun sebanyak 43 orang responden (43\%), dan responden dengan usia 20 tahun sebanyak 26 orang responden (26\%), dan untuk yang berusia $<20$ tahun sebanyak 31 orang responden $(31 \%)$.

\section{Uji Validitas}

Berdasarkan hasil uji validitas menggunakan korelasi product moment menunjukan bahwa variabel kebudayaan (X1), sosial (X2), pribadi (X3), psikologi (X4),dan keputusan konsumen 
mempunyai nilai pearson correlation lebih dari 0,195 dan semuanya bernilai positif, sehingga dapat disimpulkan bahwa semua pernyataan yang diujikan valid, artinya bahwa semua butir pernyataan (instrumen) dalam kuesioner tersebut dapat mengukur variabel penelitian.

\section{Uji Reliabilitas}

Berdasarkan hasil uji reliabilitas untuk data pre-test menunjukan bahwa semua variabel menghasilkan nilai Cronbach's alpha> 0,6 dan Cronbach's alpha if item deleted $>0,6$ sehingga dapat disimpulkan pernyataan yang digunakan dalam pengujian reliabilitas semuanya reliabel, yang berarti bahwa kuesioner yang digunakan dalam penelitian mampu memberikan hasil yang konsisten dari waktu ke waktu.

\section{Regresi Linear Berganda}

Hasil regresi berganda menunjukkan bahwa variabel bebas yakni Kebudayaan,Sosial, Pribadi, dan Psikologi berpengaruh positif terhadap variabel terikat yakni Keputusan Pembelian, dengan nilai koefisien determinasi (R2) sebesar 0,676 ini berarti seluruh variabel bebas (X) mempunyai kontribusi sebesar $67 \%$ terhadap variabel terikat (Y). Sisanya sebesar 33\% dipengaruhi oleh faktor-faktor lain yang tidak masuk dalam penelitian.
Berdasarkan hasil regresi berganda menunjukkan Fhitung sebesar 61,590, sedangkan hasil Ftabel pada tabel distribusi pada tingkat kesalahan 5\% atau 0,05 adalah sebesar 2,47. Hal ini berarti $\mathrm{F}$ hitung $>\mathrm{F}$ tabel $(49,591>2,47)$, hal tersebut menunjukan bahwa variabel (X) secara bersama-sama mempunyai pengaruh yang positif dan signifikan terhadap variabel(Y).

\section{Pembahasan}

Hasil pengujian validitas data diperoleh item pernyataan variabel reward dinyatakan valid karena mempunyai nilai pearson correlation lebih dari Ftabel. Sedangkan hasil uji reliabilitas menunjukan bahwa nilai cronbach alpha dari tiap-tiap variabel lebih besar Cronbach's alpha if item deleted yang berarti bahwa kuisioner yang digunakan yang diambil dari indikator-indikator variabel tersebut reliable atau handal

Berdasarkan hasil Persamaan regresi linier berganda digunakan untuk mengetahui seberapah besar nilai keputusan konsumen bila nilai variabel kebudayaan, sosial, pribadi, dan psikologis berubah. Berdasarkan persamaan regresi linier berganda maka dapat di ketahui bahwa jika nilai dari variabel terikat meningkat maka akan mempengaruhi variabel terikat, dalam hal ini jika variabel kebudayaan, sosial 
meningkat maka akan mempenaruhi keputusan konsumen.

Dari hasil penelitian dapat dilihat bahwa variabel pribadi memiliki pengaruh yang paling besar terhadap keputusan konsumen, karena faktor pendapatan memiliki andil yang cukup besar dalam mempengaruhi keputusan konsumen. Faktor sosial juga memiliki pengaruh dalam keputusan konsumen yaitu dari segi pergaulan maupun lingkungan keluarga juga berpengaruh. Sedangkan dari faktor budaya sendiri memiliki pengaruh yang paling kecil dari ke empat variabel karena mahasiswa kurang menganggap penggunaan transportasi online sebagai sebuah budaya masyarakat modern saat ini tapi sebagai sebuah kebutuhan, dan faktor psikologis sendiri memiliki pengaruh yang positif karena mahasiswa sebagai konsumen sebagian besar merasakan pelayanan yang baik dari Grab Car.

\section{Kesimpulan}

Berdasarkan hasil penelitian, maka dapat disimpulkan bahwa:

Dari empat variabel yang mempengruhi keputusan penggunaan Grab Car Faktor Kebudayaan, sosial, pribadi, dan psikologi secara simultan atau bersama-sama mempunyai pengaruh yang positif dan signifikan terhadap keputusan konsumen, dan variabel yang dominan adalah pribadi, denganT hitung lebih besar dibandingkan variabel lainnya, karena penggunaan grab car oleh mahasiswa sangat dipengaruhi oleh faktor pendapatan dan ekonomi. Dengan nilai koefisien determinasi $\left(\mathrm{R}_{2}\right)$ sebesar 0,676 ini berarti seluruh variabel $\mathrm{X}$ yakni kebudayaan, sosial, pribadi dan psikologi mempunyai kontribusi sebesar $67 \%$ terhadap keputusan penggunaan Grab Car oleh mahasiswa Fakultas Ilmu Sosial Dan Politik Universitas Sam Ratulangi Manado Sisanya merupakan faktor lain yang tidak diteliti.

\section{Saran}

Dari hasil penelitiaan dan sejalan dengan kesimpulan yang ada peneliti dapat memberikan saran yaitu:

Pengaruh Faktor Pribadi yang terdiri dari usia dan tahap siklus hidup, pekerjaan, situasi ekonomi, gaya hidup, kepribadian dan konsep diri menjadi pertimbangan konsumen dalam mengambil keputusan untuk menggunakan Grab Car, maka perusahaan (GRAB) harus lebih cermat dalam mengindentifikasi kebutuhan konsumen yang diteliti yaitu mahasiswa, terlihat bahwa keputusan pembelian mereka tidak mudah dipengaruhi oleh orang lain melainkan dari pribadi masing-masing. Sehingga faktor harga dan kualitas pelayanan menjadi pertimbangan tersendiri. 


\section{Daftar Pustaka}

Agustin, A. 2017. "Presepsi Masyarakat Terhadap Penggunaan Transportasi Online (Gojek) di Surabaya dalam Jurnal Ilmu dan Riset Manajemen", Volume 6, Nomor 9, September 2017.

Kotler, Philip dan Keler, Kevin, 2012. "Manajemen Pemasaran", Edisi 12 Erlangga Jakarta

Maleke, C, .L. 2013. "Faktor Sosial, Pribadi, dan Psikologis Pengaruhnya Terhadap Keputusan Pembelian Blackberry Gemini Pada PT. Megamitra Makmur Sejahtra", Jurnal EMBA 553 Vol. 1 No. 3 September 2013.

Towoliu, J.E.S. "Pengaruh Faktor Pribadi dan Faktor Keluarga Terhadap Keputusan Pembelian di Rumah Makan Waroeng Tepi Laut Manado", Jurnal EMBA Vol. 5 No. 2 Juni 2017.

Syafirah. 2017 "Pengaruh Faktor-faktor Perilaku Konsumen Terhadap Keputusan Pembelian Produk Holland Bakery Manado", Jurnal EMBA Vol. 5 No. 2 Juni 2017

http://.www.ejournal.unsrat.ac.id/index.php/em ba/article/view/2104 